\title{
Association Between Lighting Level to Subjective Complaints of Visual Fatigue on Operators in the Auto Welder Section
}

\section{Hubungan Tingkat Pencahayaan terhadap Keluhan Subjektif Kelelahan Mata Pada Operator Welder Auto}

\author{
Edza Aria Wikurendra' ${ }^{1,2}$, Muhammad Shafly Rabbani ${ }^{3}$, Globila Nurika ${ }^{4}$ \\ ${ }^{1}$ Doctoral School of Management and Organizational Science, Faculty of Economic Science, Hungarian \\ University of Agriculture and Life Science, 7400, Kaposvár, Guba Sándor Utca 40, Hungary \\ ${ }^{2}$ Public Health Study Program, Faculty of Health, Nahdlatul Ulama University of Surabaya, \\ Jalan Raya Jemursari No.57, Surabaya, East Java 60237, Indonesia \\ ${ }^{3}$ Public Health Center of Lape, Health Office of Sumbawa Regency, Lape Sub-District, Sumbawa Regency, \\ West Nusa Tenggara Province, 84382, Indonesia \\ ${ }^{4}$ Public Health Study Program, Faculty of Public Health, University of Jember, \\ Jalan Kalimantan No.37, Jember Regency, East Java, 68121, Indonesia
}

\begin{abstract}
Introduction: Good intensity of light dramatically affects the eyes. If there is less intensity of light. the eye muscles contract as much as possible to see objects or vice versa. If this happens continuously, it will cause damage to the eyes. Based on the preliminary study, it was found that as the auto welder operators have the task to observe the results of the auto welder engine to determine the quality of the welder, this type of work needs accuracy so that the right lighting intensity is required. This study aimed to determine the association between the lighting level and subjective visual fatigue complaints on operators in the auto welder section. Methods: The research method used was quantitative, with a crosssectional approach and observational method. The samples in this study were 18 respondents from the total sampling technique. The instrument used was the Visual Fatigue Index (VTI) questionnaire. Moreover, the analysis of the study results used the one sample T-test statistical test to determine the association between the dependent and independent variables. Results: The one sample T-test results showed $p$-value $=0.012<\alpha=0.05$. This result showed an association between the lighting leveland subjective visual fatigue complaints on operators in the auto welder section. Conclusion: In this research, it was found that the majority of lighting levels that did not meet the standards had an association with subjective complaints of visual fatigue on the operators in the auto welder section.
\end{abstract}

Keywords: auto welder, lighting, visual fatigue

\section{ABSTRAK}

Pendahuluan: Intensitas cahaya yang baik sangat mempengaruhi mata, jika cahaya yang kurang otot mata harus berkontraksi semaksimum mungkin untuk melihat objek atau sebaliknya, jika ini terjadi terus menerus dapat menyebabkan kerusakan pada mata. Berdasarkan studi pendahuluan yang di lakukan, operator welder auto memiliki tugas untuk mengamati hasil dari mesin welder auto untuk mengetahui kualitas welder, jenis pekerjaan ini merupakan pekerjaan yang memerlukan ketelitian sehingga memerlukan intensitas pencahayaan yang baik. Penelitian ini bertujuan untuk mengetahui hubungan tingkat pencahayaan terhadap keluhan subjektif kelelahan mata pada operator di bagian welder auto. Metode: Metode Penelitian yang di gunakan adalah kuantitatif, dengan pendekatan cross sectional dengan metode observasional. Sampel dalam penelitian ini sebanyak 18 responden dengan menggunakan teknik total sempling. Instrumen yang digunakan yaitu kuesioner Visual Fatigue Index. penelitian ini menggunakan Uji statistik one sample T-test untuk mengetahui hubungan variabel dependen dan independen. Hasil: Hasil hasil uji one sample T-test menunjukkan $p$ value $=0.012<\alpha=0.05$ hasil ini menunjukkan terdapat hubungan antara tingkat pencahayaan terhadap keluhan subjektif kelelahan mata pada operator di bagian welder auta. Simpulan: Pada penelitian ini didapatkan tingkat pencahayaan yang mayoritas tidak memenuhi standar memiliki hubungan dengan keluhan subyektif kelelahan mata pada operator di bagian welder auto.

Kata kunci: kelelahan mata, pencahayaan, welder auto 


\section{Corresponding Author:}

Edza Aria Wikurendra

Email: edza.wikurendra@phd.uni-szie.hu

Telephone: +36204330931

\section{INTRODUCTION}

In the world of work, interactions between humans, work tools, and the work environment cannot be avoided, involving the human senses either directly or indirectly. One of the human body parts that are often involved, which cannot be separated from work, is the eye. The eyes are a part of the worker's body that must be protected for safety and health. Sufficient light is, therefore, one of the most critical aspects that determine eye health. Good lighting allows workers to select work objects quickly and without unnecessary effort. Right light intensity also significantly affects the eye. If the light is lacking, the eye muscles must contract as much as possible to see objects or vice versa, and if this happens continuously, it can cause damage to the eye (Rahmayanti and Artha, 2016).

One of the factors that influence an operator's physical work environment's quality is the lighting intensity. Lighting is some irradiation in a field of work needed to carry out activities effectively. The function of lighting in the work area includes providing lighting to objects that are the operator's work, such as machines or equipment, production processes, and the work environment (Rahmayanti and Artha, 2016).

The lack of light intensity in a workspace is related to visual fatigue in the workers. Symptoms of visual fatigue can limit personal activities so that they have an impact on future work results and have the potential to cause age-related visual impairment. Several studies have found that visual fatigue is also associated with systemic symptoms and psychological status, but this is still a matter of debate (Ananda and Dinata, 2015). This is in line with the Decree of the Minister of Health Number 1405 of 2002, concerning Requirements for Industrial Work Environment, suggesting that lighting in the room for types of routine work activities, such as office/ administration work, control room, machine work, and assemblyshould compose the minimum lighting level of $300 \mathrm{Lux}$ (Health Ministry, 2002).

Visual fatigue is visual discomfort, which includes pain or throbbing sensation around the eyes, double vision, blurred vision, difficulty in focusing, sore eyes, red eyes, watery eyes, headaches, and nausea. The leading cause of visual fatigue is fatigue of the ciliary muscles and extraocular muscles due to prolonged accommodation, especially during activities that require close vision. The severity of visual fatigue depends on the type of training, intensity, and the work environment (Ananda and Dinata, 2015).

Previous research analyzing the strength level of lighting againts eye fatigue in Garuda Lhokseumawe futsal sport field showed the effect of light intensity on visual fatigue on users of the Garuda Futsal Arena Lhokseumawe (Badriana, 2018). Meanwhile, for operators in the welder auto section, no references or previous studies have been found. Researchers, therefore, consider it necessary to measure the auto welder's lighting because it also risks visual fatigue.

Based on the preliminary survey conducted, the auto welder job is a type of work that requires accuracy, so it requires a standard lighting intensity of at least 300 Lux. For lighting sources that are used during the day, the work uses natural lighting from the sun because part of the roof of the building uses fiberglass so that it allows sunlight to enter, while at night it uses artificial lighting that comes from lights in the production building, and also additional lighting nearby the auto welder machine. Based on the description above, it is known that the type of work performed by auto welder operators requires accuracy, so it requires lighting intensity under standards. Therefore, researchers are interested in investigating the association between the lighting intensity and subjective visual fatigue complaints on operators in the auto welder section.

\section{METHODS}

The method used in this study was an observational method with a cross-sectional approach design. The population in this study was 18 operators in the auto welder section at PT. Arthawena Saktigemilang, Malang. The sampling technique used was a total sampling with a sample of 18 people. This research was conducted from June 2018 to August 2018.

There were two kinds of research variables used, namely the independent variable and the dependent variable. The independent variable was the level of lighting, and the dependent variable was the subjective complaints of eye fatigue.

Data collection used a Visual Fatigue Index (VFI) questionnaire based on the Industrial Fatigue 
Research Committee (IFRC). Meanwhile, the measurement of eye fatigue variables used a Visual Fatigue Index (VFI) questionnaire consisting of 22 questions with alternative answers: Never (score 1), Sometimes (score 2), Often (score 3) and Always (score 4). Lighting measurements were based on the Minister of Health Decree Number 1405 of 2002, concerning Requirements for Industrial Work Environment, and lighting in the room, for types of routine work activities, such as office/ administration work, control room, machine work, and assembly shouldcompose the minimum lighting level of 300 Lux. Thus, if the result of lighting measurement is below 300 Lux, it is considered not eligible and if the result of lighting measurement is above 300 Lux, it is considered eligible. The lighting measurement used in this research was the local lighting intensity when the workers were doing the welding work, and the level was measured using a lux meter as a measuring tool, which was done at 6 measurement points on each shift. Analysis of the study results used the one sample T-test statistical test to determine the association between th dependent and independent variables. This research has passed the ethical test with a letter number 012/ EC/KEPK/ UNUSA/2018.

\section{RESULTS}

In this study, the data were obtained through questionnaires/ individuals, and the lighting measurements were based on the Minister of Health Decree Number 1405 of 2002, concerning Requirements for Industrial Work Environment, suggesting that lighting in the room for types of routine work activities, such as office/ administration work, control room, machine work, and assemblyshould compose the minimum lighting level of 300 Lux.

\section{Lighting Level}

Lighting is a part of various types of electromagnetic waves that fly into space. These waves have a specific length and frequency whose values are distinguished from other light energies in the electromagnetic spectrum. According to the Decree of the Minister of Health Number 1405 of 2002, the lighting standard for routine work using machines is 300 lux. The lighting measurement carried out in this study was the intensity of local lighting with natural light sources when the workers were doing welding work, and the result was measured using a lux meter as a measuring tool. This was carried out at 6 measurement points, specifically 3 points in the north building and 3 points in the south building; the measurements were taken on each shift. The results of the measurement of the level of lighting on the welder operators can be seen in Table 1.

Table 1 shows that most of the lighting conditions received by operators in the auto welder section did not meet the Minister of Health Decree Number 1405 of 2002. In detail, ten measurement locations $(55.56 \%)$ didnot meet the requirements.

\section{Subjective Complaints of Visual Fatigue}

Subjective complaints of visual fatigue are complaints of visual fatigue felt by the operators on the auto welder section. The distribution was based on the Visual Fatigue Index (VFI) questionnaire given to respondents, which had beendivided into two characteristics, either not tired (below 0.4) ortired (above 0.4 ). The research results on the subjective complaint category of visual fatigue felt by the operators on the auto welder section can be seen in Table 2.

Table 2 shows that from a total of 18 operators, the number of operators who experienced visual fatigue complaints was six people (33.34\%). The most dominant complaint experienced by welding workers was reduced eye accommodation power. This complaint was experienced at work and was still felt when workers were on vacation, especially for workers who were on day shifts due to longer working hours.

Table 1. Lighting Condition of Operators in the Auto Welder Section at PT. Arthawena Saktigemilang in 2018

\begin{tabular}{ccc}
\hline Lighting Category & $\mathbf{n}$ & $\mathbf{\%}$ \\
\hline Eligible & 8 & 44.44 \\
Not eligible & 10 & 55.56 \\
\hline Total & 18 & 100.00 \\
\hline
\end{tabular}

Table 2. Visual Fatigue Conditions of Operators in the Auto Welder Section at PT. Arthawena Saktigemilang in 2018

\begin{tabular}{ccc}
\hline $\begin{array}{c}\text { Category of Visual } \\
\text { Fatigue }\end{array}$ & n & \% \\
\hline Complaints & 6 & 33.34 \\
No complaints & 12 & 66.66 \\
\hline Total & 18 & 100.00 \\
\hline
\end{tabular}


Table 3. Tabulation Between Lighting Levels and Subjective Complaints of Visual Fatigue onOperators in the Auto Welder Section at PT. Arthawena Saktigemilang

\begin{tabular}{ccccc}
\hline \multirow{2}{*}{ Variable } & \multicolumn{2}{c}{ Lighting Category } & \\
\cline { 3 - 4 } & $\mathbf{N}$ & $\begin{array}{c}\text { o } \\
\text { Eligible }\end{array}$ & Eligible & Total \\
\hline Visual & Complaints & 4 & 2 & 6 \\
Fatigue & No complaints & 6 & 6 & 12 \\
\hline
\end{tabular}

Table 4. One sample T-test Analysis for the Association Between Lighting Levels and Subjective Complaints of Visual Fatigue of Operators in the Auto Welder Section at PT. Arthawena Saktigemilang

\begin{tabular}{ccc}
\hline Variable & N & Sig. \\
\hline $\begin{array}{c}\text { Lighting Levels } \\
\begin{array}{c}\text { Subjective Complaints } \\
\text { of Visual Fatigue }\end{array}\end{array}$ & 18 & 0.037 \\
\hline
\end{tabular}

\section{Association Between the Lighting Level and Subjective Complaints of Visual Fatigue}

Cross-tabulation between the variables of lighting levels and subjective complaints of visual fatigue can be seen in Table 3. Table 3 shows that six respondents experienced subjective complaints of visual fatigue $(33.33 \%), t$ two of which $(11.11 \%)$ operated a welder machine with good lighting values In contrast, four people $(22.22 \%)$ did not get an adequate level of lighting. Proving the association between lighting levels and subjective complaints of visual fatigue on operators in the auto welder section, a statistical test analysis was performed using one sample T-test with the following results:

Based on Table 4, the one sample T-test analysis results obtained a significant value of 0.037 (p-value $\leq 0.05$ ), which means that the data were significant and $\mathrm{H} 1$ was accepted, indicating a relationship between lighting and subjective complaints of visual fatigue.

\section{DISCUSSION}

\section{Lighting Level}

The lighting level measurement showed that most of the operators' lighting conditions at the auto welder section did not meet the requirements, particularly at ten measurement locations $(55.56 \%)$. The fiberglass's shape on the roof of the building functioned as a light entryway when the lighting measurements were taken in dirty conditions. This blocked sunlight from entering and causedthe difference in lighting intensity at each measurement location. Also, some operators added lighting in the form of lights placed near the welder machine. Based on the interview results, adding additional lights would cause an increased room temperature to interfere with work comfort. The use of incandescent lamps as a source of artificial lighting has the disadvantage of emitting radiation. The surface temperature can reach $60^{\circ} \mathrm{C}$ or more, so the room feels uncomfortable, and incandescent lights also give a warm psychological impression that the light color is reddish yellow (Azhara, 2014).

Low-intensity lighting can cause visual fatigue, eye strain, and complaints of soreness around the eyes. However, when the light intensity is high, it can also cause glare to interfere with work. Therefore, efforts must be made for lighting with sufficient and adequate power, which is neither too low nor too high (Santoso, 2013).

There is an increase in workers' visual performance after some interventions to improve the intensity of lighting in the workplace and to reduce the number of workers who experience visual fatigue (Zakerian et al., 2018). Inadequate lighting will cause the pupil to dilate, which results in decreased visual acuity. The eyes will find it challenging to focus on objects and sensitivity to contrast, which increases the effect of glare (Jasna and Dahlan, 2019).

The cone photoreceptors that control the accommodation process increase, resulting in continuous contraction of the ciliary muscles. Then, the oxygen supply decreases and stimulates anaerobic glycolysis, resulting in a buildup of lactic acid, which causes pain, stress, and fatigue in the eye muscles (Khoiriyah, Jayanti and Widjasena, 2019).

\section{Subjective Complaints of Visual Fatigue}

Subjective complaints of eye fatigue on the operators at the auto welder section showed that out of 18 operators, the number of operators who experienced visual fatigue complaints were six people $(33.34 \%)$. Previous research conducted on computer users at Teerhanker Mahaver University found that the main complaint suffered was eyestrain (tired eyes) with a proportion of 53\% (Kumbar and Yee, 2019). Another study on call center employees in Metro Manila found complaints on eye strain, dry eyes, and eye pain suffered by the respondents, of 
$66.8 \%, 45.8 \%$, and $42.6 \%$ respectively. The results of his study also assessed the correlation between the three. The incidence of eye strain and eye pain has a reliable correlation with the length of time working at the office's computer and working hours. In contrast, the incidence of dry eye has a strong correlation with the size of working at the computer a day and strongly correlates with the length of time working at the office (Cabrera and Lim-Bon-Siong, 2010).

Visual and musculoskeletal complaints among computer workers in Delhi reported that the incidence of watery eyes $(23.2 \%)$ was higher than that of irritated eyes (18.6\%) (Talwar et al., 2009), in contrast to the results of other studies which found that the incidence of eye irritation was higher than that of watery eyes. However, the difference was not significant (Das and Ghosh, 2011). Despite the contradictory results, they both suggested the same results about the causes of watery eyes and irritated eyes, namely the reflection of light and shadows formed on the monitor. Placing the monitor at a level lower than the eye can reduce eye fatigue. By looking down, it means that there is more eye surface area covered by the eyelid so that the eye blinks more frequently (Wolska, 2019).

\section{Association Between Lighting Level to Subjective Complaints of Visual Fatigue}

The one sample T-test analysis results showed a significant value of 0.037 ( $\mathrm{p}$-value $\leq 0.05$ ), meaning that the data were significant. Also, H1 was accepted, indicating a significant relationship between lighting and subjective complaints of eye fatigue. Several factors can cause this, such as the age of the respondents who were over 45 years old and the absence of internal training from the company to the welder operators.

Moreover, age has a significant relationship with accommodation power. As we get older, the eye lens will decrease its elasticity and gradually lose its elasticity, and the ability of vision accommodation decreases at the age of 45-50 years old (Badriana, 2018). This statement is also supported by previous research on the relationship of age and lighting to subjective complaints of visual fatigue among the Pasar Raya tailors, which stated that there was a relationship between age and subjective complaints of visual fatigue among the tailors of the Pasar Raya Padang City (Anne, 2016).

Internal training from the company to welder operators is believed to be able to reduce the risk of developing occupational diseases. One factor affecting health and safety is the employee's factor, including the absence of knowledge and ability (Firmanzah, Hamid and Djudi, 2017). This statement is also supported by other research, which stated that there was a significant influence between training on occupational health and safety for employees of CV. Bangkit Sukses Makmur (Kartika, 2015).

\section{CONCLUSION}

The result of this researchshowed that there was a significant association between lighting and subjective complaints of visual fatigue on the operators at the auto welder section.

\section{ACKNOWLEDGEMENTS}

Our thanks go to all parties involved, as well as Nahdlatul Ulama University of Surabaya, Public Health Center of Lape and University of Jember.

\section{REFERENCES}

Ananda, N. S. and Dinata, I. M. K. (2015) 'Hubungan Intensitas Pencahayaan Dengan Keluhan Subjektif Kelelahan Mata Pada Mahasiswa Semester II Program Studi Pendidikan Dokter Fakultas Kedokteran Universitas Udayana, Tahun 2015', E-Jurnal Medika Udayana, 4(7), pp. 1-10.

Anne, S. (2016) Hubungan Umur, Durasi Kerja dan Pencahayaan dengan Keluhan Subjektif Kelelahan Mata Pada Penjahit Pasar Raya Kota Padang Tahun 2016. Diploma thesis. Padang; Faculty of Public Health, Universitas Andalas.

Azhara (2014) Gambaran Pemenuhan Standar Pencahayaan Perpustakaan Fakultas Kedokteran dan Ilmu Kesehatan Universitas Islam Negeri Syarif Hidayatullah Jakarta Tahun 2014. Undergarduate Thesis. Jakarta: Faculty of Medicine and Health Sciences, Universitas Islam Negeri Syarif Hidayatullah.

Badriana (2018) 'Analisa Tingkat Kuat Penerangan Terhadap Kelelahan Mata Pada Pencahayaan Lapangan Olah Raga Futsal Garuda Lhokseumawe', Jurnal Elektro dan Telkomunikasi, 4(2), pp. 5-14.

Cabrera, S. and Lim-Bon-Siong, R. (2010) 'A Survey of Eye-Related Complaints among Call-Center Agents in Metro Manila', Philippine Journal of Ophthalmology, 35(2), pp. 65-69.

Das, B. and Ghosh, T. (2011) 'Assessment of Ergonomical and Occupational Health Related Problems Among VDT Workers of West Bengal, 
India', Asian Journal of Medical Sciences, 1(2), pp. 26-31.

Firmanzah, A., Hamid, D. and Djudi, M. (2017) 'Pengaruh Keselamatan Dan Kesehatan Kerja Terhadap Kinerja Karyawan (Studi Pada Karyawan PT. PLN (Persero) Area Kediri Distribusi Jawa Timur)', Jurnal Administrasi Bisnis, 42(2), pp. $1-9$.

Health Ministry, R. I. (2002) 'Decree of the Minister of Health of the Republic of Indonesia Number 1405 concerning Health Requirements for the Work Environment', Jakarta.

Jasna, J. and Dahlan, M. (2019) 'Hubungan Intensitas Pencahayaan Dengan Kelelahan Mata Pada Pekerja Penjahit Di Kabupaten Polewali Mandar', J-KESMAS: Jurnal Kesehatan Masyarakat, 4(1), pp. 48-58.

Kartika, H. (2015) 'Pengaruh Pelatihan Terhadap kesehatan Dan Keselamatan Kerja (Studi pada Karyawan Bagian Produksi CV. Bangkit Sukses Makmur)', Jurnal Administrasi Bisnis, 26(2), pp. 1-6.

Khoiriyah, I. A., Jayanti, S. and Widjasena, B. (2019) 'Hubungan Intensitas Pencahayaan, Kelelahan Mata Dan Gangguan Ketajaman Penglihatan Pada Pekerja Bagian Inspecting PT. Tekstil X', Jurnal Kesehatan Masyarakat (e-Journal), 7(4), pp. 67-73.
Kumbar, L. and Yee, J. (2019) 'Current Concepts in Hemodialysis Vascular Access Infections', Advances in Chronic Kidney Disease, 26(1), pp. 16-22.

Rahmayanti, D. and Artha, A. (2016) 'Analisis Bahaya Fisik: Hubungan Tingkat Pencahayaan dan Keluhan Mata Pekerja pada Area Perkantoran Health, Safety, and Environmental (HSE) PT. Pertamina RU VI Balongan', Jurnal Optimasi Sistem Industri, 14(1), pp. 71-98.

Santoso, G. (2013) 'Manajemen Kelelahan Kerja', Jakarta: Prestasi Pustaka Publisher.

Talwar, R. et al. (2009) 'A study of Visual and Musculoskeletal Health Disorders among Computer Professionals in NCR Delhi', Indian Journal of Community Medicine, 34(4), pp. 326-328.

Wolska, A. (2019) 'Lighting of VDT Workstands and Users' Visual Discomfort-Results of an Experimental Study', Human-Centered Computing: Cognitive, Social, and Ergonomic Aspects, 3, p. 153.

Zakerian, S. A. et al. (2018) 'The Effect of Increasing the Illumination on Operators' Visual Performance in the Control-Room of a Combined Cycle Power Plant', Annals of Occupational and Environmental Medicine, 30(1), pp. 1-7. 